\title{
Contemporary Trends in the Use of Khat for Recreational Purposes and Its Possible Health Implications
}

\author{
Micah O. Omare ${ }^{1,2}$, Joshua K. Kibet ${ }^{3 *}$, Jackson K. Cherutoi1',2, Fredick O. Kengara ${ }^{1,2,4}$ \\ ${ }^{1}$ Department of Physical and Biological Science, Moi University, Eldoret, Kenya \\ ${ }^{2}$ Africa Center of Excellence II in Phytochemicals, Textiles and Renewable Energy (ACE II PTRE), Moi University, Eldoret, Kenya \\ ${ }^{3}$ Department of Chemistry, Egerton University, Egerton, Kenya \\ ${ }^{4}$ Department of Chemistry, Bomet University College, Bomet, Kenya \\ Email: *jkibet@egerton.ac.ke
}

How to cite this paper: Omare, M.O., Kibet, J.K., Cherutoi, J.K. and Kengara, F.O. (2020) Contemporary Trends in the Use of Khat for Recreational Purposes and Its Possible Health Implications. Open Access Library Journal, 7: e6985.

https://doi.org/10.4236/oalib.1106985

Received: November 12, 2020

Accepted: December 28, 2020

Published: December 31, 2020

Copyright $\odot 2020$ by author(s) and Open Access Library Inc.

This work is licensed under the Creative Commons Attribution International License (CC BY 4.0).

http://creativecommons.org/licenses/by/4.0/

\section{(c) (i) Open Access}

\begin{abstract}
Khat is an ancient class $\mathrm{C}$ drug substance that is usually consumed for its stimulating effects induced by the intake of psychoactive alkaloids-cathinone and cathine which have been identified as precursors for oral cancer and impotence in men in addition to other health complications. Although khat is legal in Kenya, some countries have outlawed the cultivation, sale and possession of khat as a countermeasure against narcotic and psychotropic substances. The increasing trends in the use of khat among the youth and adults of all races in the world, regardless of its associated dangers, are worrying. This paper seeks to explore the emerging trends on the use of khat and the chemical compounds generated responsible for psychoactive behaviour. Nonetheless, the health implications of repeated khat use and the challenges it poses in the management of the Coronavirus disease-2019 (Covid-19) have been reviewed and reported in this work. Possible toxicological consequences are discussed in detail. A literature search was done by targeting articles published within the period of 2012-2020 in PubMed, Crossref, Google Scholar and Web of Science. The articles were picked if they contained information on khat use, trends in khat use, health effects and Covid-19 management using khat. Various techniques by which khat is consumed including oral chewing, smoking, and sprinkling, bombing and keying were identified and discussed in this work. A range of chemical compounds present in khat and their associated toxicological health impacts linked to khat consumption have been presented from the literature surveyed. Nonetheless, the medicinal aspects of khat use with recommendations from a medical perspective are also discussed. Molecular modelling of selected psychoactive compounds generated from khat smoking is also presented in this study. Results showed that
\end{abstract}


cathinone breaks down to yield benzenyl and 3-aminobuytanyl-2-one radicals that react with hydride and metals to yield carcinogenic benzene molecule and C-centered environmentally persistence free radicals, respectively. Furthermore, the HOMO an LUMO structures for these organic molecules illustrates that they act as nucleophiles that can react with electrophilic unsaturated human bio-molecules such as amino acids and lipids to initiate shifts in pi-electrons and dienophile electrons resulting in gene alterations and mutation. Accordingly, khat chewing can be regarded as a possibly serious practice that may aid in the present spread of SARS-Cov-2-virus and manifestation of other health concerns such as cancer. This study identifies campaigns against khat chewing, cessation and abstinence as strategies against the associated negative health impacts of khat. These findings are important in facilitating policy makers to make informed decisions for control and consummation of khat as a possible narcotic substance.

\section{Subject Areas}

Environmental Chemistry

\section{Keywords}

Cathinone, Toxicity, Carcinogenicity, Khat Smoking

\section{Introduction}

Khat comprises of leave shoots and is cultivated and chewed by millions of East Africans and Arabs in Arabian Peninsula for its stimulating effects induced by amphetamines-cathinone and cathine indicated in Figure 1(a) and Figure 1 (b), respectively. Once the drugs gain entry into the human brain they initiate pleasurable effects and machismo tendencies [1]. This plant substance is known by other names such as qat, chat, qaadka, mairungu, muhulo, hagigat miraa, kijiti, gomba, veve, African salad, Abyssinian tea and tschat; all depending on the country of origin [2] [3]. Even though khat is classified as a class $\mathrm{C}$ drug by the world health organization (WHO), khat cultivation, use and possession are legalized in Kenya and most East African countries but some nations such as South Africa, Bangladesh, Canada, the state of California and some other states in the United States of America (USA), have criminalized its use and possession [4] [5] [6]. Consequently, khat and its chemical compounds cathinone and cathine, have been marked as restricted materials by the Controlled Substances Act (CSA) and the Drug Enforcement Administration (DEA) in schedule I and IV, respectively [7].

Khat chewing is a well-known cultural tradition and a recreational activity that is practiced in a range of social amenities by both young and old [3]. Individuals get motivated and addicted to chewing khat due to its high psychoactive ingredients; cathinone and cathine which act symphathomimetically on the cen- 
tral nervous system (CNS) and directly influences both the central dopaminergic and peripheral noradrenergic presynaptic sites to produce mild euphoric excitement, manic behaviors, hyperactivity, hallucinations, and a calming effect within a period of 30 minutes from the time of consumption [3] [8]. Although cathine also contributes to the CNS stimulation characteristics, it has been reported to be less potent in fresh khat leaves by previous studies than cathinone [9]. Figure 2 gives a summary of khat plantation through harvesting, packaging, marketing and consumption. Khat harvesting involves the plucking of the buds, tender twigs and leaves by individuals, using their naked hands to groups of people packaging khat in bundles using banana leaves as shown in Figure 2(b) and Figure 2(c), depending on the quantity desired by the intended market.<smiles>CC(N)C(=O)c1ccccc1</smiles>

(a)<smiles>C[C@@H](N)[C@H](O)c1ccccc1</smiles>

(b)

Figure 1. Khat alkaloids (a) cathinone (b) cathine.

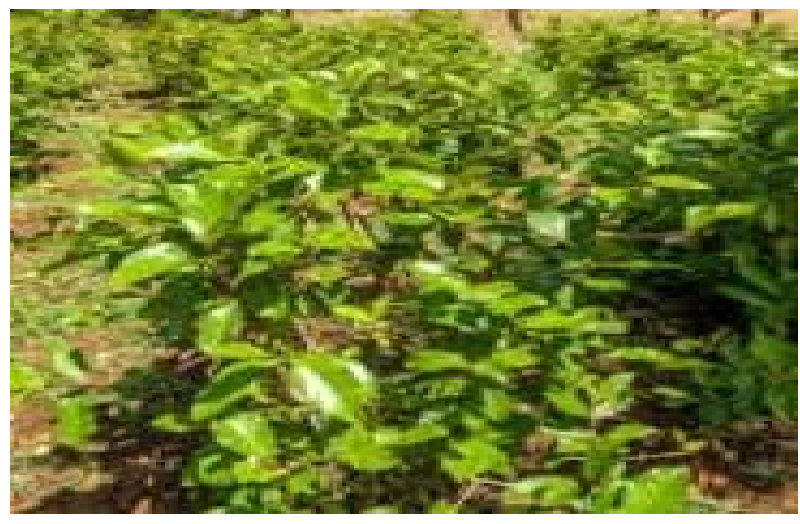

(a)

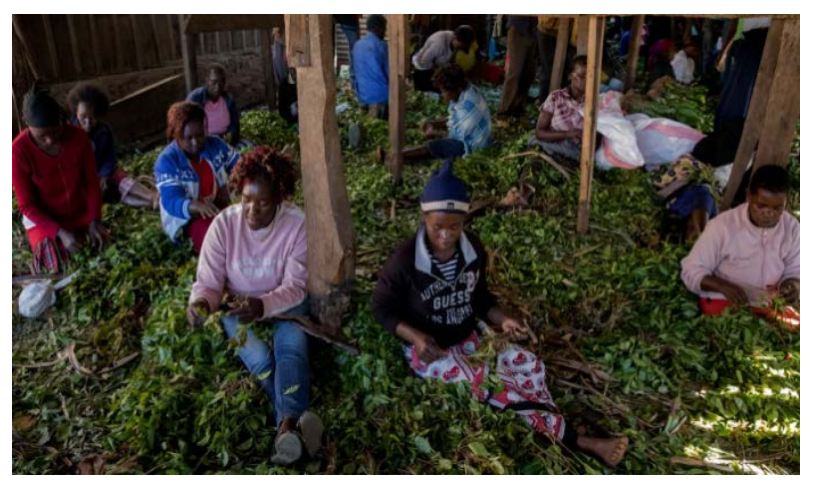

(c)

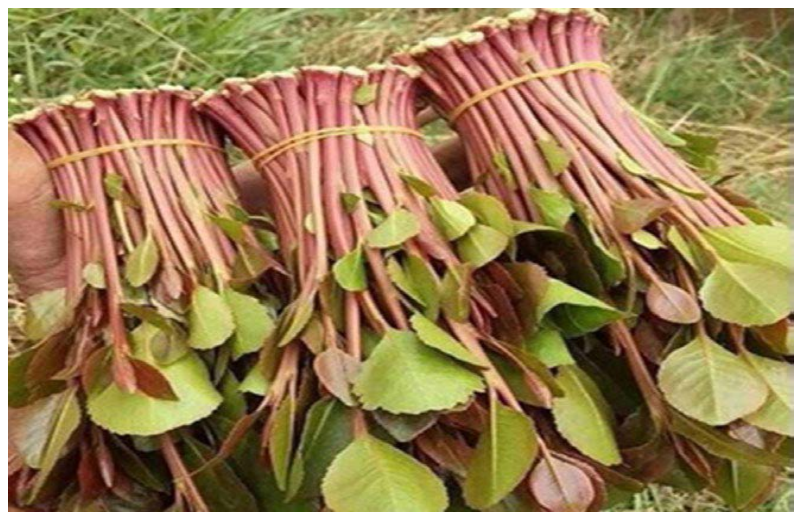

(b)

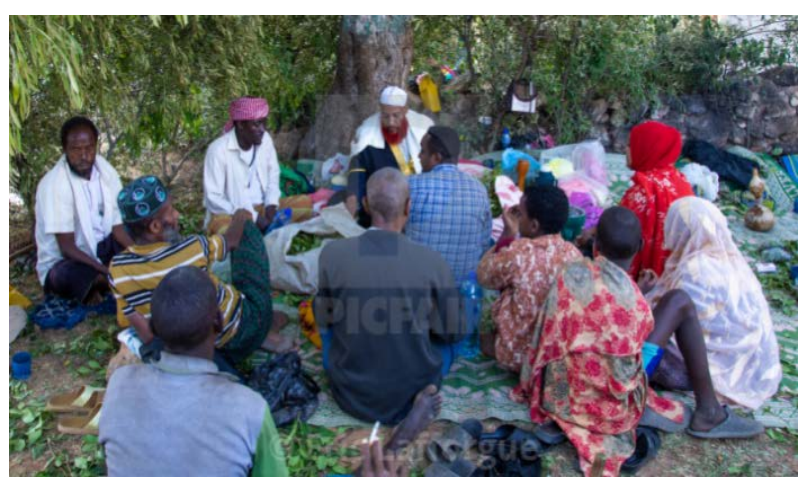

(d)

Figure 2. (a) Khat plantation; (b) fresh khat bundles; (c) khat packaging; (d) men and women chewing khat-photos adopted from [10] [11] [12] [13]. 
Even though various scientific studies have explored and characterized the chemical composition of khat, there is still minimal documentation in literature that extensively reports on khat epidemiological data [14]. Notably, in the contemporary society, there are reports on increased khat transit and exportation destined to the USA and the United Kingdom (UK) where the herb is considered illegal [15]. These trends are worrying especially with regard to the associated health effects arising from prolonged use of khat. Accordingly, deleterious effects and health complications such as oral cancer, gastric and oesophageal carcinoma, and oral mucosa genetic damage have been noted among habitual khat chewers [16]. These health issues constitute khat toxicity outcomes whose elucidation remains a subject of interest given that there is lack of comprehensive scientific studies that have explored its harm. Thus khat is a public health concern [17]. For these reasons therefore, this study aims at identifying documented and emerging trends in the use of khat, health challenges and complications that arise from its repeated use, as a subject of grave public health across the world. Traditionally, khat chewing is performed among groups of people as a recreational activity by most communities in Eastern Africa and the Arabian Peninsula, although individuals can chew khat privately at their own convenience. This work will also briefly explore the challenges posed by khat consumption in the management of Covid-19 pandemic.

\section{Methodology}

In order to obtain relevant information for this study, keywords such as khat (qat, chat, qaadka, mairungu, muhulo, hagigat miraa, kijiti, gomba, and veve) abuse, addiction, khat toxicology, khat and SARS-Cov-2, pharmacology and carcinogenicity were used and comprehensively searched for in the literature published between January 2012 and October 2020 on PubMed, Google scholar, Web of Science, Cochrane and online scientific electronic library websites from May 2020 to September 2020. Cathine and cathinone were explored by their chemistry, effects and toxicology in order to pool relevant literature. The search outputs were saved in databases and authors notified on searches that met the search criteria whenever there was need.

\section{Results and Discussions}

\subsection{Emerging Trends in Techniques Used for the Consumption of Khat}

The method by which khat is consumed greatly determines the stimulating and psycho-effects induced on the user due to variations in the concentration levels of the major alkaloids of khat that depend on the freshness of the leaves and twigs. For instance, cathinone and cathine are found in higher concentrations in fresh leaves compared to dry leaves which are considered less potent and less addictive [10] [18]. There are various oral methods by which this drug substance can be ingested. The traditional method involves chewing fresh leaves, twigs, 
and shoots, which are reserved in the cheek and further masticated intermittently and spasmodically in order to discharge the active drug ingredients in form of "juice" which are extracted by enzyme action and consequently dissolved in saliva, swallowed and absorbed through the buccal mucosa and gastro-intestinal tract [17] [19] [20]. During khat chewing, individuals sometimes take a sip of water to prevent mouth dryness, or a sip of soda or a pinch of sugar to mitigate its bitter taste [13] [21]. In some cases, the khat dried material is made into tea or a chewable paste [22]. Nonetheless, khat leaves can be smoked by crushing dried leaves which are then rolled into cigars or ground into powder and sprinkled on food [3] [10] [22] [23]. The method used for khat consumption depends on the cultural practice of the community, social status, and economy, political and spiritual lives [21]. Capsules and tablets that are designed with synthetic cathinones in white and brown amorphous and crystalline powders contain other compounds such as mephedrone, methylone, naphyrone, butylone, methcathinone, pyrovalerone, 4-fluoromethcathinone, 3,4-methylenedioxypyrovalerone, and methedrone ingredients, often used in illicit markets-although they are less common [24] [25].

The sole reason for khat use is stimulating effects contributed largely by cathinone and cathine ingredients, although unstable cathinone decomposes into cathine once the fresh khat leaves get exposed to oxygen after harvesting, during withering or when dry and therefore, khat leaves are commonly chewed when fresh in order to offer maximum psychotropic effects [26]. Remarkably, the other methods listed in Table 1 have minimal but increased popularity in their use, given that the stimulating effects require more amounts of the drug to be ingested

Table 1 . The popularity of khat consumption techniques and procedures.

\begin{tabular}{|c|c|c|c|c|}
\hline $\begin{array}{l}\text { Method of } \\
\text { intake }\end{array}$ & Designed technique & $\begin{array}{l}\text { Popularity } \\
\text { percentage }\end{array}$ & $\begin{array}{l}\text { Trend in the } \\
\text { last } 1 \text { decade }\end{array}$ & Reference \\
\hline chewing & $\begin{array}{c}\text { Fresh twigs and leaves chewed for } \\
\text { mucosal absorption }\end{array}$ & $80 \%$ & increasing & [13] [17] \\
\hline smoking & $\begin{array}{c}\text { Dried khat leaves rolled into } \\
\text { smoked cigars }\end{array}$ & $30 \%$ & increasing & [3] [10] \\
\hline khat tea & $\begin{array}{l}\text { Dried and grinded khat leaves packaged } \\
\text { into sachets that are added into hot } \\
\text { water for drinking. }\end{array}$ & $27 \%$ & increasing & [3] \\
\hline khat paste & $\begin{array}{c}\text { Dried khat leaves made into } \\
\text { chewable paste }\end{array}$ & $31 \%$ & increasing & [3] \\
\hline $\begin{array}{c}\text { khat food } \\
\text { powder }\end{array}$ & $\begin{array}{l}\text { Dried khat leaves are finely } \\
\text { grinded into powder sprinkled } \\
\text { onto food during eating }\end{array}$ & $23 \%$ & increasing & [10] \\
\hline Capsules/tablets & $\begin{array}{l}\text { Bombing: cathinone derivative powder } \\
\text { rolled into cigar paper and swallowed. } \\
\text { Keying: insufflation of } 8 \text { keys per gram } \\
\text { of cathinone derivative by key dipping } \\
\text { into powder. }\end{array}$ & unknown & increasing & $\begin{array}{c}{[24][25]} \\
{[27][28]} \\
{[29]}\end{array}$ \\
\hline
\end{tabular}


or longer time periods to be manifested in the user due to lowered levels of cathinone-the chief khat stimulant that usually induces its psycho-stimulating activity in 1 to 3 hours after the chewing onset. Regardless of these assumptions, capsules and tablets which encompass synthetic cathinones have gained increasing popularity, widespread availability and are sold as "bath salts" or "plant food" commonly over internet website markets and drug suppliers and consumed by ingestion or nasal insufflation [27]. Bombing and keying form the basic techniques by which synthetic cathinones are consumed-bombing technique involves wrapping a fine cathinone derivative powder, usually comprising of mephedrone, in a cigarette paper and is then swallowed, while keying encompasses the act of dipping a key into finely ground khat powder followed by insufflation [27] [28].

\subsection{Emerging Chemical Compounds from Khat and Their Carcinogenicity}

Khat phytochemicals include tannins, flavonoids, sterols, glycosides, terpenoids, vitamins $\mathrm{C}$, carbohydrates, amino acids, thiamin, niacin, riboflavin, noncyclic nitrogen containing compounds, and about 62 alkaloids [13] [30] [31]. The stimulating activity of khat is mainly contributed by alkaloids; phenylalkylamines, which constitute cathinone [S-(-)-cathinone], and two cathine diasteriomers [1S, 2S-(+)-norpseudoephedrine] and norephedrine, [1R, 2S-(-)-norephedrine as indicated in Figure 3(a), Figure 3(b) and Figure 3(c), respectively. The S-(-)- cathinone enantiomer is the only one that has been reported to be present in khat and has a structural stereochemistry resembling that of S-(+)-amphetamine (Figure 3(d)) but differ in their pharmacological action [32]. The instability of cathinone causes its decomposition leading to the formation of the "dimer" (3,6-dimethyl-2,5-diphenylpyrazine) during withering and drying processes of khat [29]. In addition, 62 cathedulins which are basically euonyminol polyesters (Figure 4(d)), resulting from poly hydroxylation of sesquiterpenes have been reported to be present in khat leaves [33]. Many other phenylalkylamine alkaloids such as merucathinone, merucathine and pseudomerucathine (Figures 4(a)-(c), respectively) with less stimulating effects have been reported in khat leaves [31].

Even though the mutagenic and carcinogenic potential of phenylalkylamines and alkaloids of khat are poorly examined, a handful of experimental and epidemiological surveys have confirmed it to exhibit teratogenic, mutagenic, and clastogenic activities of cathinone in human cells [34]. Hassan et al. [35] has demonstrated that chronic khat chewing promotes carcinogenic processes in humans by initiating endogenous oxidative damage in the DNA cells, and expression of oesophageal and fore stomach carcinomas in khat chewers which have been attributed to khat leaves' ability to undergo nitrolisation in the gut to produce nitrosamines [36]. In addition, khat contains a high concentrated of tannins that have been highly linked to oesophageal cell carcinoma and oral malignancy [34]. 
<smiles>C[C@H](N)C(=O)c1ccccc1</smiles>

(a)<smiles>C[C@H](N)[C@H](O)c1ccccc1</smiles>

(b)<smiles>C[C@@H](N)[C@H](O)c1ccccc1</smiles>

(c)<smiles>C[C@H](N)Cc1ccccc1</smiles>

(d)<smiles>NC[C@@H](O)c1ccccc1</smiles>

(e)

Figure 3. (a) S-(-)-cathinone; (b) 1S, 2S-(+)-norpseudoephedrine; (c) 1R, 2S-(-)-nore- phedrine; (d) (+)-S-amphetamine; (e) R-(-)-noradrenaline.<smiles>C[C@@H](N)C(=O)/C=C/c1ccccc1</smiles>

(a)<smiles>C[C@H](N)[C@H](O)/C=C/c1ccccc1</smiles>

(b)<smiles>[CH2][C@H](O)[C@H](O)/C=C/c1ccccc1</smiles>

(c)

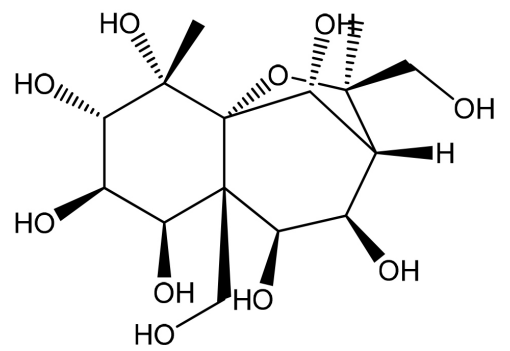

(d)

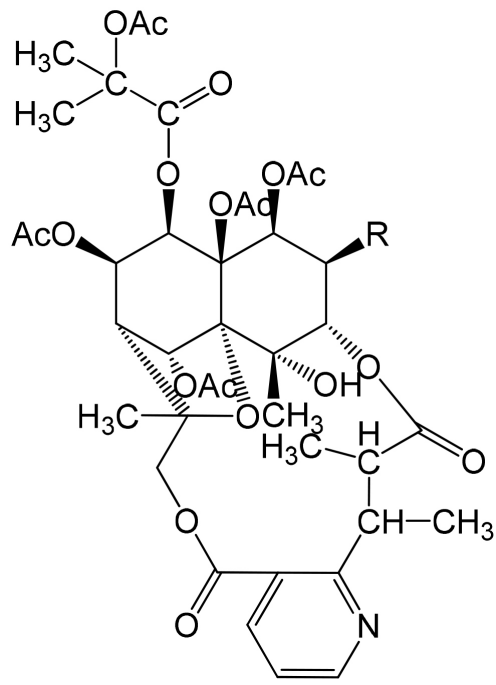

(e)

Figure 4. (a) (+)-S-merucathinone; (b) (-)-3S, 4S-pseudomerucathine; (c) (+)-3R, 4Smerucathine; (d) euonyminol; (e) catheduline. 


\subsection{Harm and Health Impacts Arising from Consumption of Khat}

Chronic khat chewing has been linked to a number of health complications and effects on human biological systems such as the respiratory, cardiovascular, hepatobiliary, genitourinary, endocrine and digestive systems by various scientific and epidemiological surveys [19] [37]. These systems are characterized by khat effects that include metabolic and weight related complications, cancers of the aero digestive system including oral cancer, ischemic heart disease, neuropsychological disease, liver complications, endocrine disruption, sexual disorder and hypertension [19] [35] [38]. For instance, grave effects such as tachycardia, palpitations, hypertension, arrhythmias, vasoconstriction, myocardial infection, cerebral hemorrhage, and pulmonary edema are manifested in the cardiovascular system, tachypnea and bronchitis in the respiratory system, dry mouth, polydipsia, dental caries and periodontal disease, chronic gastritis, hemorrhoids, duodenal ulcers and upper gastro-intestinal malignancy in the gastro intestinal system, fibrosis and cirrhosis in the hepatobiliary system in addition to urinary retention, spermatorrhea, spermatozoa malfunctions, impotence and libido change which affect the genitourinary system [34] [36] [39]. Moreover, salivary gland infection, plasma cell gingivitis, teeth attrition and discoloration, temporomandibular joint disorder, and keratotic white lesions including mucosal lesions are other health issues that have reportedly been induced by chronic khat chewing [13]. Figure 5 gives a summary of the biological health effects of khat use.

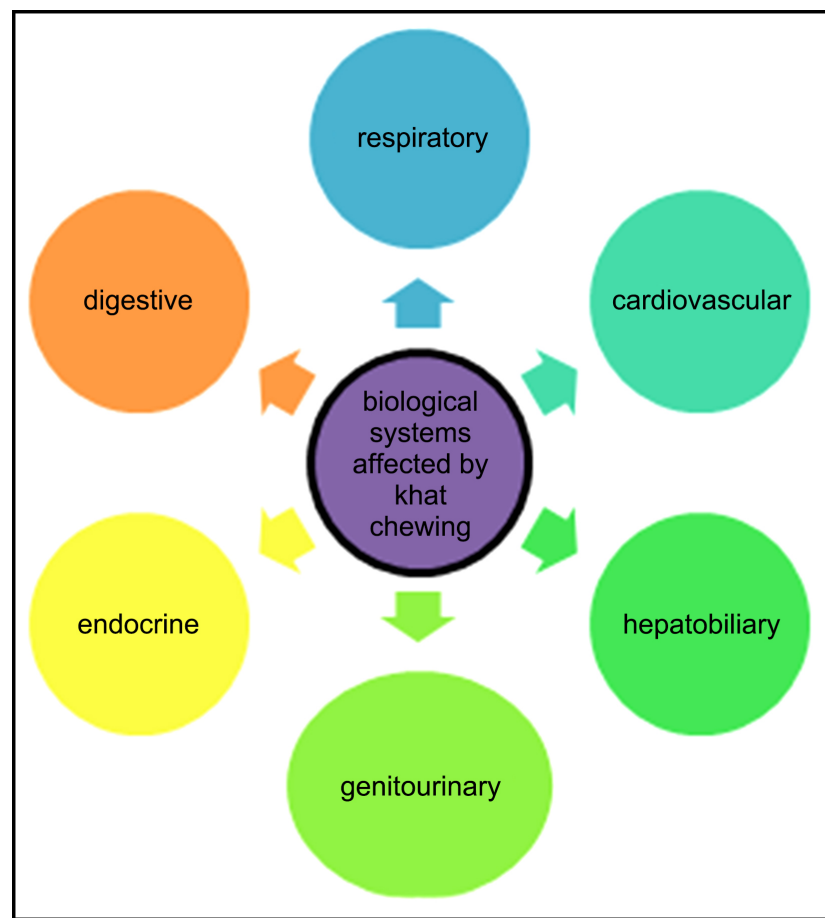

(a)

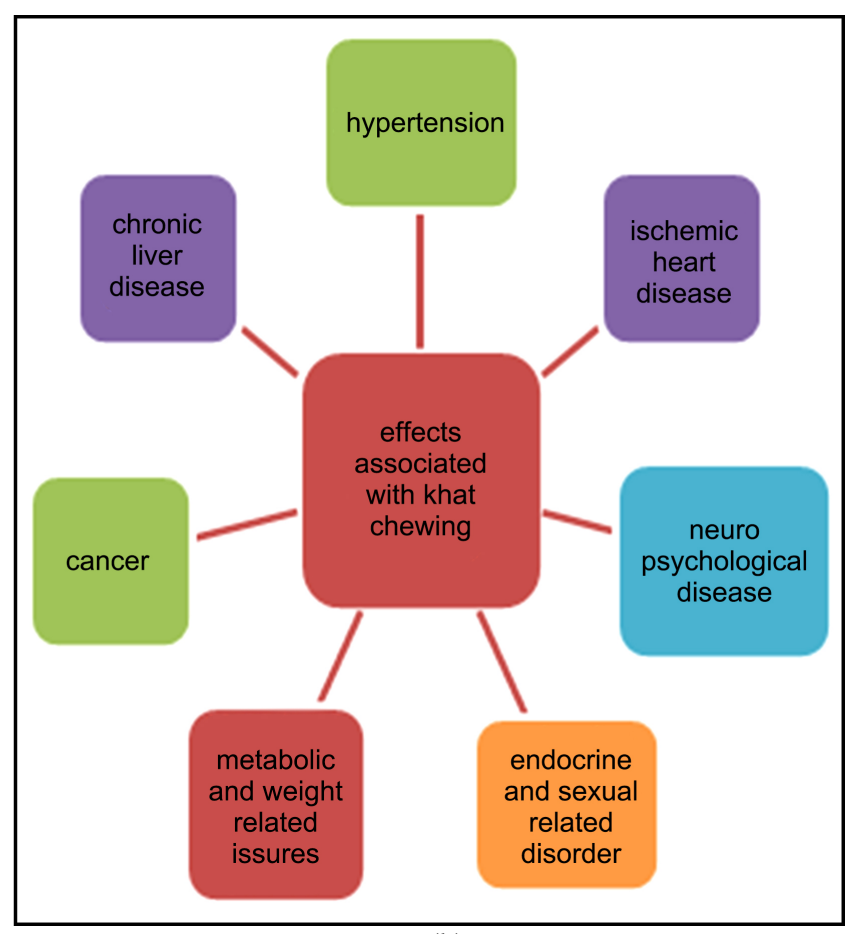

(b)

Figure 5. (a) Biological systems affected by khat chewing; (b) health effects associated with khat chewing [35] [37] [38] [40] [41]. 
Regardless of the possible toxicological impacts of khat, a number of studies have reported medicinal application of khat for the management of diabetes, muscle strength, depression, obesity, male infertility and cancer. Interestingly, a study conducted by Lu et al. (2017) demonstrated the cytotoxic effects of khat extracts on breast cancer and came up with findings showing that khat suppresses breast cancer by inducing apoptosis of the breast cancer cells [37].

\subsection{Challenges Posed by Khat in the Management of the Covid-19}

Coronavirus disease 2019 (Covid 19) is a global pandemic which is caused by the severe acute respiratory syndrome Coronavirus 2 (SARS Cov-2), a zoonotic virus ecologically believed to originate from wild animals such as bats [42] [43]. The medical fraternity across the world has experienced an agonizing task in the management of Covid-19 because of the lack of effective medication and specific antiviral therapy recommended for its management and treatment. Currently, there are a set behavioral standards as a strategy to containing the spread of the disease in humans which include individuals observing social distancing, wearing of face masks, restrictions on social gatherings, minimizing contact on public areas, hand sanitizing and washing among the few safety measures that can reduce contact and minimize exposure and spread of the virus [44] [45]. The practice of khat chewing has posed immense challenges with regard to the management of covid-19 and aided its rapid spread from the point of harvest consummation, and marketing. Khat harvesting is an activity that occurs throughout the year in order to maintain market demands for continuous supply [46]. The khat harvesting and packaging processes evokes a lot of concerns in regard to controlling the spread of coronavirus if the prevention and safety measures may be ignored by any infected individual. For instance, proper hand washing and sanitization before and during harvesting and packaging processes may not be observed and this may be a precursor for transmission of the virus onto the plucked twigs and leaves (environmental shedding) and the materials used for packaging (banana leaves), or if the person is infected by the SARS-Cov-2 sneezes or coughs. Such an action will transmit viral droplets which may settle on the surfaces of the khat leaves and consequently the virus gets transferred to the hands, and ultimately initiating self-inoculation [47]. Coronavirus is known to live on surfaces for long hours with the survival period depending on the nature of the material with which the surface is made of [48]. Because harvested khat is required to be transported immediately to destined markets and chewed when still fresh for maximum pleasurable effect, usually within 2 to 48 hours; it can be predicted that there are high chances of the SARS-Cov-2 surviving on packaged khat. Therefore, the virus finds entry into the users' biosystem through the mouth during khat chewing effectively promoting viral spread and transmission. Furthermore, khat chewing is usually done by both men and women seated together in groups during a range of social amenities without necessarily observing some stipulated health regulations such as keeping social distancing and 
wearing of face masks. In some instances, there is occasional sharing of soft drinks in a common glass and periodical spitting of saliva-acts which are likely to enhance inter-person viral transmission therefore, precipitating a challenge in the fight against Covid-19 pandemic.

\subsection{Computational Modeling Profiles for Selected Molecular Compounds in Khat}

In order to gain a thorough understanding on the structural relationship and properties of chemical compounds that define atomic combinations and molecule stoichiometry, applications of designed computational codes that simulate physical experiments play a major role because they predict physical and chemical changes taking place inside real systems in reactions occurring at varying conditions [49] [50]. Computational codes are structured with variables that are representative of systems under investigation and which can be adjusted either singly or in combinations and observations in correspondence to the actuated alterations are made on outcomes during simulations that aid researchers in giving relevant conclusions [50]. These developed computer programs have been proven to enhance and expedited scientific research and offer real time accuracy in results compared to experimental data [51] [52]. Accordingly, selected molecular compounds from khat; cathinone (S-(-)-cathinone), two cathine diasteriomers (1S, 2S-(+)-norpseudoephedrine) and norephedrine (1R, 2S-(-)-norephedrine) considered the main addictive khat alkaloids have been modeled using Gaussian '09 computational code at the density functional theory (DFT) quantum level coupled with B3LYP functional and $6-31++$ diffuse basis set. Notably, in the array of methods by which khat is consumed, smoking khat is gaining popularity across the world regardless of the possible toxic effluents released during smoking [3] [10]. All calculations and geometry optimization are conducted at 298.15 $\mathrm{K}$ at 1 atmosphere pressure. This is in line with the fact that there is an increasing gain of interest in health and environmental concerns on the toxicity of molecular compounds and the intermediary radicals generated from the unregulated temperatures during smoking [53]. The thermal degradation of khat just like any other biomass material generates innumerable pollutants that can potentially cause irreparable damage to human cells and sometimes reactive species which are well known precursors for oxidative stress, respiratory, pulmonary and bronchial complications in addition to cancer among other health issues as listed in Figure 5(b), vide supra [54].

\subsubsection{The Thermal Degradation of Selected Khat Alkaloids and Mechanistic Pathways}

During khat smoking, the smoker puffs the cigar under a set of uncontrolled temperatures which breaking down the components of the cigarette into a series of other chemical compounds and radicals that are potentially toxic. This work has proposed a mechanistic pathway by which selected khat alkaloids thermally degrade to yield a set of radicals and eventually convert them to other toxic 
chemical compounds. Furthermore, the associated energy changes for the formation of free radicals and chemical compounds from these alkaloids have been computed using the formula illustrated in Equation (1) [55].

$$
\Delta_{r} H^{\circ}=\sum\left(\varepsilon_{0}-H_{\text {corr }}\right)_{\text {products }}-\sum\left(\varepsilon_{0}-H_{\text {corr }}\right)_{\text {Reactants }}
$$

where, $\Delta_{r} H^{\circ}$ is change in enthalpy of the reaction, $H_{\text {corr }}$ is correction to the thermal enthalpy and $\varepsilon_{0}$ is the sum of electronic and thermal enthalpies.

Accordingly, this work has demonstrated that cathinone breaks down to yield benzenyl and 3-aminobuytanyl-2-one radicals that subsequently react with hydride to yield benzene and 3-aminobutan-2-one molecules, respectively as illustrated in Scheme 1. Benzene molecule has been reported by various scientific studies as a high risk factor for exposure to human health and an identified initiator for human cell carcinogenesis [56]. Long term exposure to benzene causes deleterious effects on human bone marrow and decreased red blood cells and consequently anemia in addition to damaging human immune systems by initiating blood antibody variation [57]. Benzene molecule reacts with environmental trace metals such as copper leading to the formation of C-centered environmentally persistent free radicals as illustrated in Scheme 1. Nonetheless, the resultant 3-aminobutan-2-one molecule undergoes further thermal degradation to produce environmentally persistent free radicals with adverse health effects particularly when heated at temperatures of about 453 to $513 \mathrm{~K}$ [58]. Clearly,

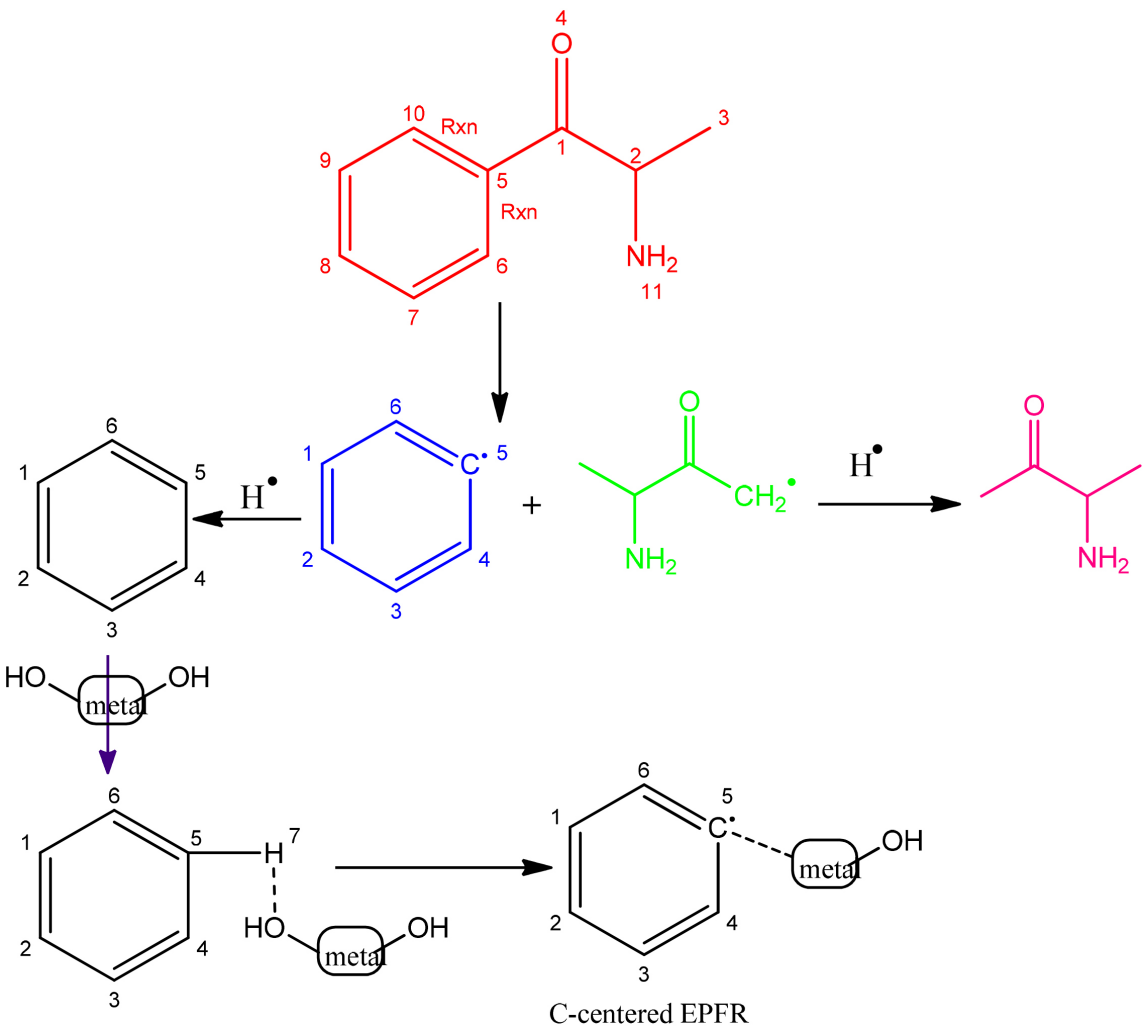

Scheme 1. Proposed mechanistic pathway for the formation of C-centered EPFR from cathinone. 
environmentally persistent free radicals that originate from human undertakings such as smoking or due to the failure of the biological activity of the catalase enzyme that initiates bio-elimination of excess free radicals from the human body systems leads to oxidative stress which has been linked to respiratory and cardiovascular diseases, and sometimes intercellular damage [59] [60].

Even though some of the formed minute molecular free radicals have been reported to environmentally exist for shorter lifetimes $\left(-10^{-9} \mathrm{~s}\right.$ for $\mathrm{OH}$ radical), it is important to note that these substances get directly trapped into the smoker's body system via the pulmonary track during smoking as a result of incomplete combustion, and due to their highly reactive nature, consequential oxidation reactions and pulmonary dysfunction occurs [60]. Accordingly, Zhu et al. [61] have reported the half-life of oxygen centered and carbon centered environmentally persistent free radicals to be 160.45 and 401.10 days respectively, and thus the formed carbon centered environmentally persistent free radicals (EFRs) from the smoked khat alkaloids. Once these radicals gain entry into the smoker's biosystems, they are likely to stay in biological systems for periods long enough to ignite biological processes that lead to devastating bio-conditions such as cardiac arrest and oxidative stress. Similarly, the aromatism exhibited by the alkaloids of khat most probably leads to the formation of benzene molecules whose reaction mechanism during thermal degradation results to the production of environmentally persistent free radicals thus increasing their concentration in the smoked effluent.

\subsubsection{Molecular Geometries of Cathinone and Major Molecular Emissions and Their Potential Energy Surfaces}

The molecular structure of any given molecule is well defined by geometric parameters including bond angles and bond lengths that significantly determine its bond strength. The molecular structure of cathinone and its corresponding molecular compounds arising from its thermal degradation are presented in scheme 1. Figures 6-9 illustrate steps undertaken towards achieving structural optimization for cathinone and its corresponding radicals. It is worth noting that cathinone gets optimized after 64 successful optimization steps at a total energy of -479.4467 Hartrees/particle. On the other hand, cathine took 22 optimization step number with a total energy of -480.6537 Hartrees/particle. Benzenyl and 3 -aminobuytanyl-2-one free radicals resulting from the thermolytic degradation of cathinone had their total energy minimization estimated at -231.5201 and -247.7814 Hartrees/particle, respectively. Remarkably, optimization steps reveal more information regarding molecule stability and the time period a molecule is likely to take in attaining its most stable geometry configuration thus enabling one to estimate the characteristic behavior of the molecule inside the biotic systems [62]. It is important to note that the longer it takes for a molecule to be optimized; the more likely it is that the molecular structure of the compound under investigation is unstable and hence considered to be more reactive in biological environments. Accordingly, the resulting radical, 3-aminobuytanyl-2-one with 

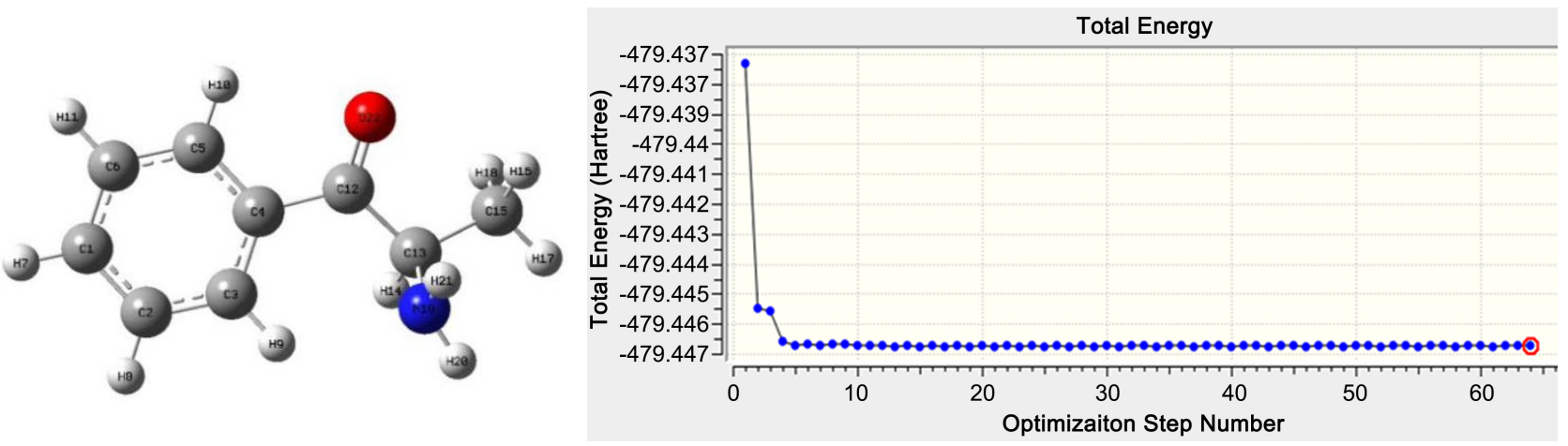

Figure 6. Cathinone optimized structure and a plot showing its optimization steps (the red circle indicates optimization level).
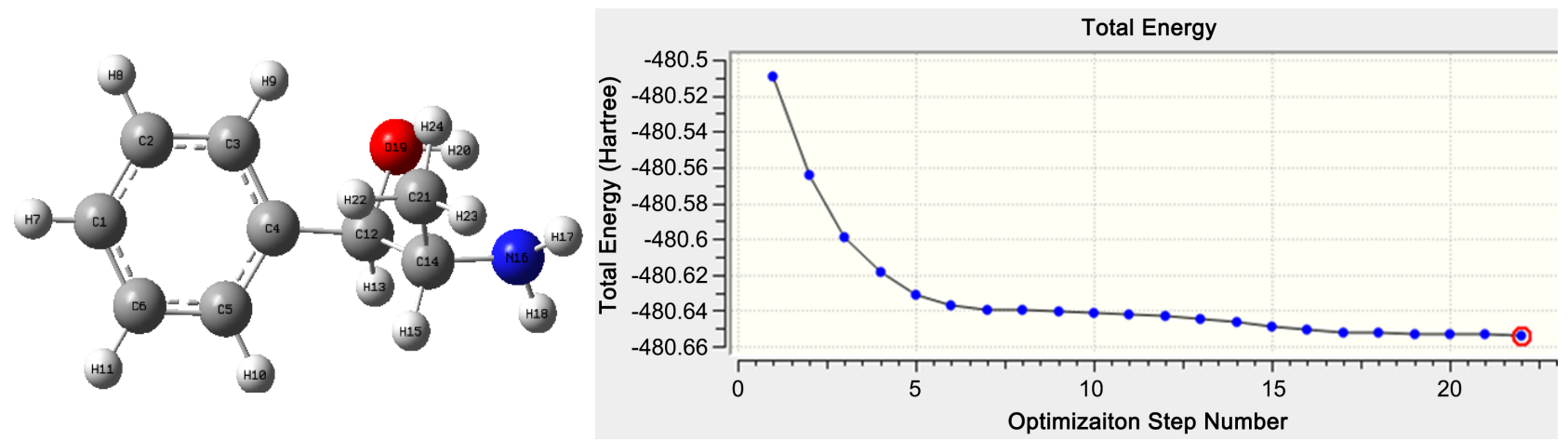

Figure 7. Cathine optimized structure and a plot showing its optimization steps.
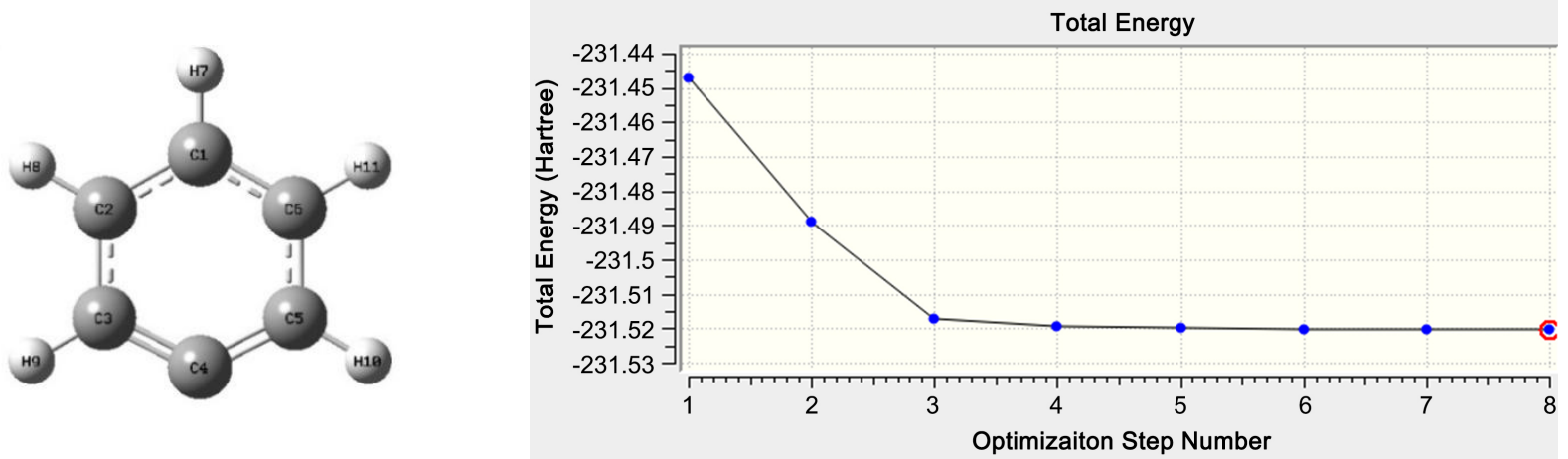

Figure 8. Benzenyl radical optimized structure and a plot showing its optimization steps.
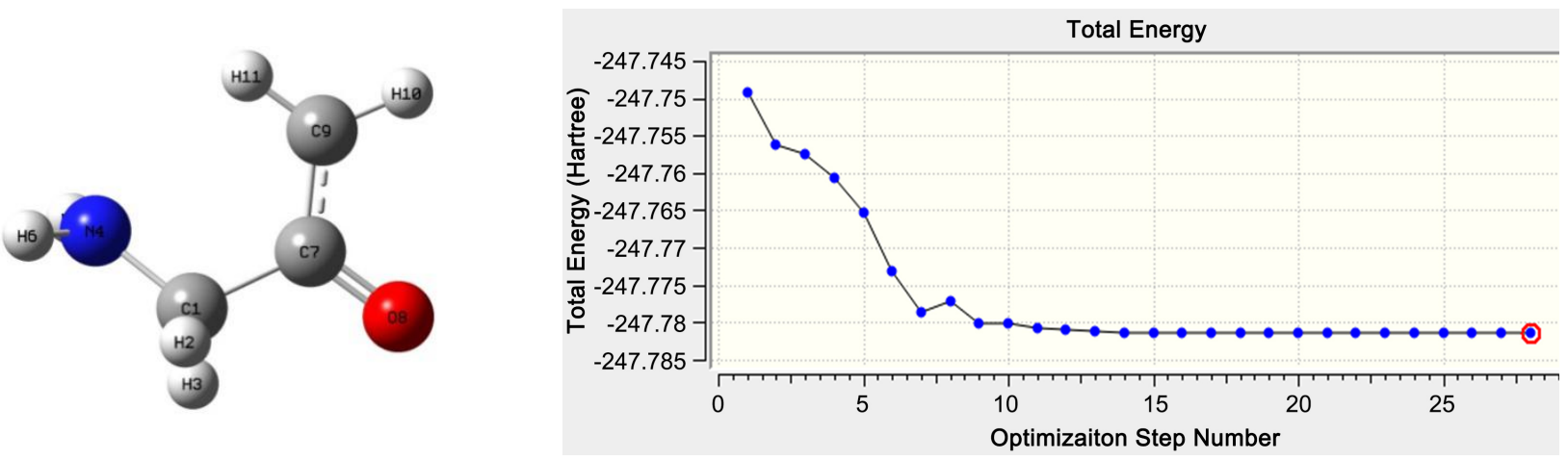

Figure 9. 3-aminobuytanyl-2-one radical optimized structure and a plot showing its optimization steps. 
28 optimization step numbers can be considered to be more toxic compared to benzenyl radical whose stability can be associated with its ability to exhibit structural resonance. In reference to these results therefore, it can be deduced that cathine with 22 optimization steps is more stable than cathinone with 64 optimization steps and therefore cathinone can be regarded as more toxic compared to cathine. Moreover, the resultant free radicals, benzenyl and 3aminobuytanyl-2-one, had 8 and 28 optimization steps, respectively. In addition, the number of optimization steps, i.e. the minimization of energy of a molecule, conceals the net inter-atomic forces acting on each atom of a given molecule which is acceptably close to zero. The energy of these systems can be described in a potential energy surface (PES) which indicates the position of the atoms.

\subsubsection{Molecular Orbitals and Electronic Properties}

Kibet et al. [63], contends that the identification of orbital structures for a molecule is required in determining the reactivity of a molecule. Consequently, the highest occupied molecuaar orbital (HOMO) and lowest occupied molecualr orbital (LUMO) energy profiles for cathinone and cathine molecules together with benzenyl radical and 3-aminobuytanyl-2-one radical obtained from their optimized geometry diagrams relating to their ionization potentials and electron affinities are presented in Figure 10 and Figure 11, respectively. The results indicate that cathinone had orbital 40 as the HOMO and orbital 41 as the LUMO at energies $-0.24019 \mathrm{eV}$ and $-0.07361 \mathrm{eV}$, correspondingly with a band gap enery diference of $0.16658 \mathrm{eV}$. Similarly, cathine exhibits orbital 37 as the highest occupied and orbital 38 as the lowest unoccupied at energies $-0.24126 \mathrm{eV}$ and $-0.0219 \mathrm{eV}$ with a band gap energy difference of $0.22017 \mathrm{eV}$ both at singlet spin, 0 charge, isovalue 0.02 and alpha occupancy.

On the other hand, the resulting radicals exhibited alpha and beta molecular orbital occupancies with duplet spins at 0 charges at an isovalue of 0.02 as illustrated in Figure 11. For instance, benzenyl radical has orbital 21 as the highest occupied alpha MO and orbital 22 as the lowest unoccupied at energies $-0.24985 \mathrm{eV}$ and $-0.02265 \mathrm{eV}$, respectively with a band gap energy difference of $0.2272 \mathrm{eV}$. Similarly, 3-aminobuytanyl-2-one displays orbital 20 as the highest occupied at an energy level of $-0.24196 \mathrm{eV}$ and orbital 21 as the lowest unoccupied at energy level $-0.0224 \mathrm{eV}$ thus giving rise to a band gap energy difference of $0.21956 \mathrm{eV}$. In comparing the band gap energies of the momlecules and their corresponding radical band gap energies, it is evident that cathinone had the smallest energy band gap, inferring that electrons get excited more readily in a cathinone molecule and readily absorb less energy for the elctrons to jump from HOMO to the LUMO compared to cathine. Because of the small energy required to cause electron excitement, the molecule becomes more reactive and hence we can deduce that cathinone can readily react with biological systems and potentially causing more fatal reactions that may lead to gene alteratons and ultimately induced carcinogenesis. 
(a)

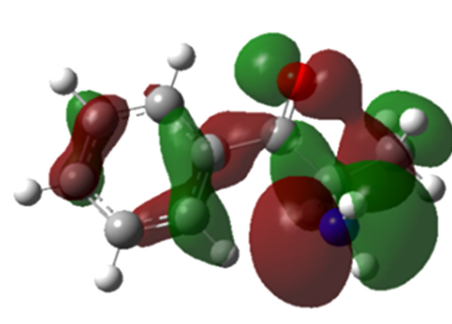

(c)

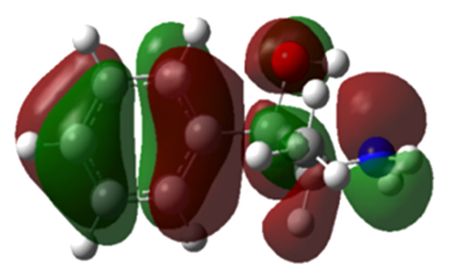

Alpha MO

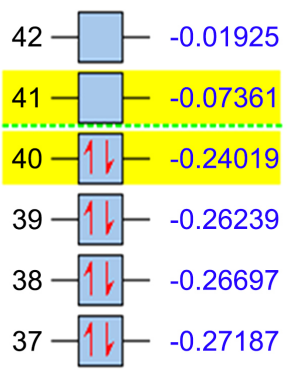

$39-\square-0.01164$

$38-\square-0.02109$

$37-11-0.24126$

$36-1 \downarrow-0.25316$

$35-11-0.26290$

$34-1$ - -0.27624 (b)

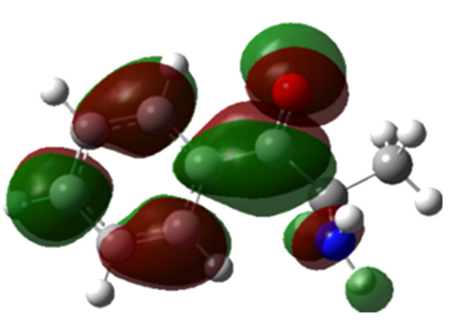

(d)

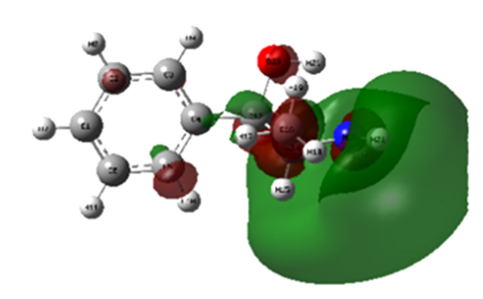

Alpha MO

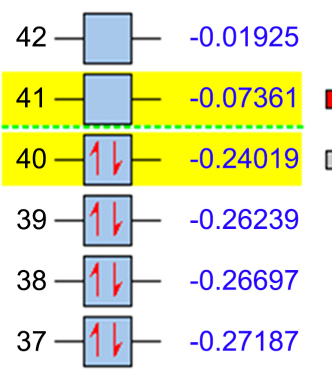

Figure 10. HOMO cathinone and cathine (a) and (c) respectively, LUMO cathinone and cathine (b) and (d) respectively

(a)

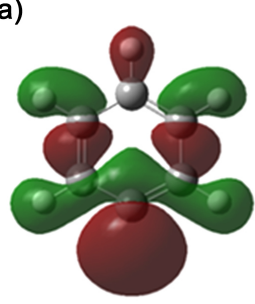

(b)

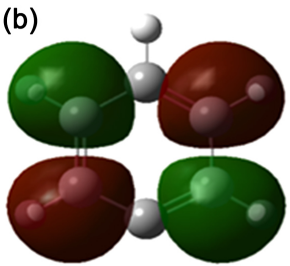

(c)

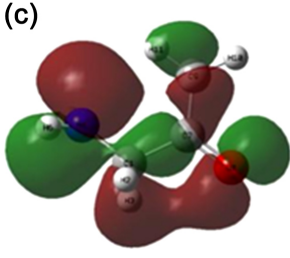

(d)

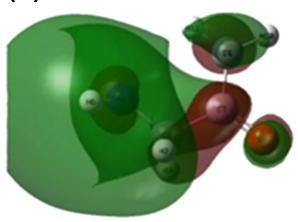

Alpha MO

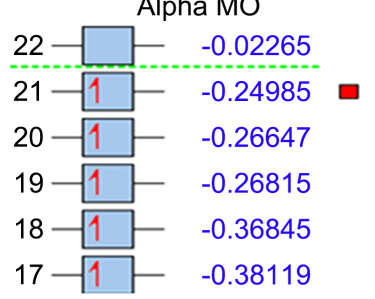

$22-\frac{-02265}{21-1}-0.24985$
$20-1$
$19-1-0.26647$
$18-1-0.26815$
$17-1-0.36845$
$-1-38119$

$21-\square-0.02240$

$20-1-0.24196$ -

$19-1-0.26511$

$18-1-0.28133$

$17-1-0.37686$

$16-1-0.40147$

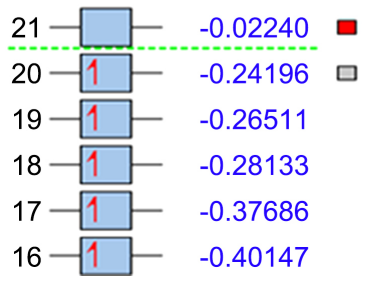

Beta MO

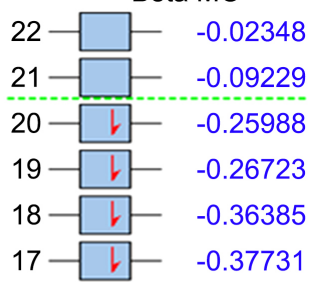

$22-\square-0.02348$

$21-\square-0.09229$

$20-\sqrt{1}-0.25988$

19 -

$18-\square$

17 - -0.37731

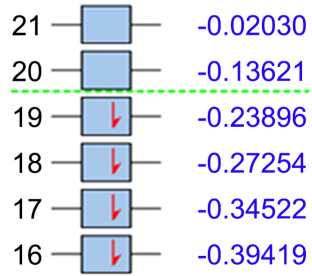

$21-\square-0.02030$

$20-\square-0.13621$

19 ㄴ -0.23896

$18-0.27254$

17 原- -0.34522

16 - -0.39419

Figure 11. HOMO benzenyl and 3-aminobuytanyl-2-one (a) and (c) respectively LUMO benzenyl and 3-aminobuytanyl-2-one radicals (c) and (d) respectively. 
Once these unsaturated organic compounds gain entry into the human bio-structures they undergo reactions that involve cyclic transition states at the double bond sites "diene" that constitute two conjugated double pi-bonds and the single bond site "dienophile, comprising of a single pi-bond due to the presence of two conjugated $\pi$-electrons systems with unsaturated molecules such as fats and lipids [64]. In the course of these reactions, these organic substances generated from the thermolytic conversions of khat act as nucleophiles (electron-rich-species) while the unsaturated bio-structure molecules act as electrophiles (electron-poor-species) occasioning possible shift of four diene $\pi$-electrons and two dienophile electrons and a corresponding conversion of $2 \pi$-bonds to 2 new durable $\sigma$-bonds in the newly formed products which may result in adverse health effects [65].

\subsubsection{Electron Density and Contour Maps}

Electron density maps for these molecules and radicals can be used to highlight the active sites for electron interactions and charge distribution for the optimized structures, and consequently an understanding of the molecule reactivity. Electron density maps indicate the high affinity interaction sites that precipitate the hydrogen bonds [66].

The values of the electrostatic potentials for any given molecule is indicated using the color codes and densities for the surfaces at the first excited state and the ground states by developing density contour maps as illustrated in Figure 12. Green regions are representative of sites with positive values with a large excited state compared to the ground state while the red site is a representation of points of high electrophilic attack. Accordingly, for cathinone, it is clear that the electron density is much concentrated around the oxygen atom and moves outwards to the benzene ring side. Similarly, there are more electrons centered on the oxygen atom and moves sideways for cathine and 3-aminobuytanyl-2-one radicals.

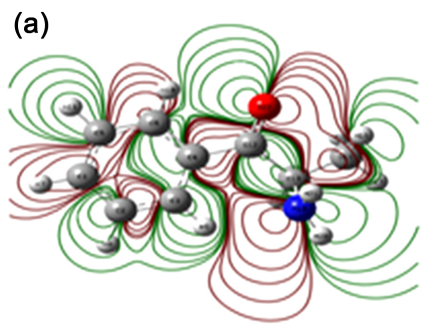

(c)

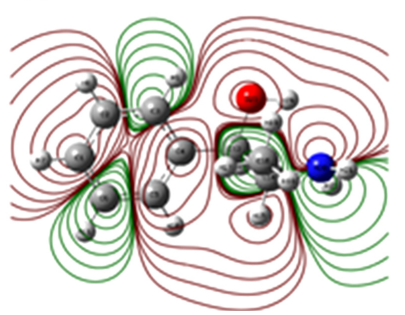

(b)

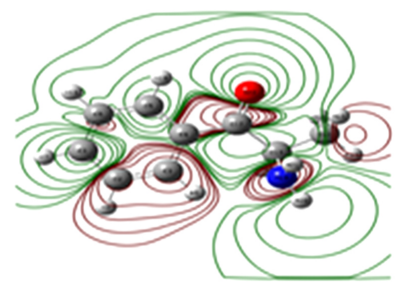

(d)

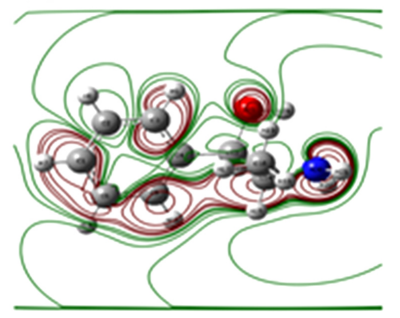

Figure 12. Electrostatic contour maps for HOMO cathinone and cathine (a) and (b), respectively and LUMO (c) and (d) for cathinone and cathine, respectively. 


\section{Conclusion}

This review has explored a number of published articles addressing khat consumption and the contemporary techniques that have been employed for its use and found out designs such as chewing, smoking, sprinkling, bombing and keying to be the common methods in use. During khat ingestion, a range of chemical compounds with a potential to affect human biological systems is generated. In this regard, khat chewing has been identified to be a toxic and carcinogenic practice even though there is a limited scientific research that has been conducted to expressively link a specific khat compound to carcinogenicity, and therefore further research is necessary to explore the carcinogenicity of khat compounds. Even though no known research has reported khat as a medicinal herb for the management of SARS-Cov-2 virus, it can be concluded that the transportation of khat to both local and international markets coupled with risky consumption habits and practices across the world may contribute to the transmission and spread of the SARS-Cov-2. Selected molecular khat compounds have been computationally modeled and the electronic properties are discussed in detail. Computational studies have demonstrated cathinone to be more reactive and potentially more toxic compared to cathine. The findings from this survey may help policy makers to formulate informative decisions on the control and use of khat as a possible narcotic substance.

\section{Acknowledgements}

The authors are thankful to the Africa Center of Excellence II in Phytochemicals, Textiles and Renewable Energy (ACE II PTRE)-Moi University and Egerton University, Division of Research and Extension for facilitating the success of this review article.

\section{Funding}

The authors are grateful to the Africa Center of Excellence II in Phytochemicals, Textiles and Renewable Energy (ACE II PTRE) and Egerton University grant \#EU/RE/DVC/072 for co-funding this research

\section{Conflicts of Interest}

The authors declare no conflicts of interest regarding the publication of this paper.

\section{References}

[1] Abebe, M., Kindie, S. and Adane, K. (2015) Adverse Health Effects of Khat: A Review. Family Medicine and Medical Science Research, 4, 2-5.

[2] Kassim, S., Dalsania, A., Nordgren, J., et al. (2015) Before the Ban-An Exploratory Study of a Local Khat Market in East London, U.K. Harm Reduction Journal, 12, 19. https://doi.org/10.1186/s12954-015-0048-Z

[3] Support for Addictions Prevention and Treatment in Africa (2012) Substances of 
Abuse. http://www.sapta.or.ke/alcohodrug-information

[4] Anderson, D. and Neil C. (2009) Khat in Colonial Kenya: A History of Prohibition and Control. The Journal of African History, 50, 377-397. Accessed December 22, 2020. http://www.jstor.org/stable/25622053

[5] Mahmud, T. (2019) Who Runs the Khat Smuggling Ring in Bangladesh. https://www.dhakatribune.com/bangladesh/crime/2018/09/24/who-runs-the-khat-s muggling-ring-in-bangladesh

[6] Law Tech Publishing Group (2016) 2016 California Penal Code Unabridged. LawTech Publishing Group, Laguna Hills.

[7] Drug Enforcement Administration (2019) Khat. https://www.deadiversion.usdoj.gov/drug_chem_info/khat.pdf

[8] Haydock, S. (2012) Drug Dependence. In: Bennett, P.N., Brown, M.J. and Sharma, P., Eds., Clinical Pharmacology, 11th Edition, Churchill Livingstone, London, 136-159. https://doi.org/10.1016/B978-0-7020-4084-9.00050-1

[9] Glennon, R.A. (2014) Bath Salts, Mephedrone, and Methylenedioxypyrovalerone as Emerging Illicit Drugs That Will Need Targeted Therapeutic Intervention. Advances in Pharmacology, 69, 581-620. https://doi.org/10.1016/B978-0-12-420118-7.00015-9

[10] Laura, C., Scot, T., Ryan, K., Sophie, S., Nitara, O. and Kristina, A. (2019) What Are the Effects of Khat? https://sunrisehouse.com/herbal-drugs/khat/

[11] Gudata, Z.G., Cochrane, L. and Imana, G. (2019) An Assessment of Khat Consumption Habit and Its Linkage to Household Economies and Work Culture: The Case of Harar City. PLoS ONE, 14, e0224606. https://doi.org/10.1371/journal.pone.0224606

[12] Brussels, E.L. (2018) Harari Men Chewing Khat during a Sufi Celebration, Harari Region, Harare, Ethiopia.

https://www.picfair.com/pics/08171147-harari-men-chewing-khat-during-a-sufi-cel ebration-harari-region-harar

[13] Al-Maweri, S.A., Warnakulasuriya, S. and Samran, A. (2018) Khat (Catha edulis) and Its Oral Health Effects: An Updated Review. Journal of Investigative and Clinical Dentistry, 9, e12288. https://doi.org/10.1111/jicd.12288

[14] Davies, S., Johnston, A. and Holt, D. (2016) Forensic Toxicology: Drug Use and Misuse. Royal Society of Chemistry, London.

[15] Corkery, J.M. (2016) Khat-Chewing It Over: Continuing 'Cultural Cement', Cardiac Challenge or Catalyst for Change? In: Davies, S., Johnston, A. and Holt, D., Eds., Forensic Toxicology-Drug Use and Misuse, Royal Society of Chemistry, London, 165-207.

[16] Math, M.V. and Kattimani, Y.R. (2016) Khat and Cancer. British Dental Journal, 221, 212. https://doi.org/10.1038/sj.bdj.2016.620

[17] Feng, L.-Y., Battulga, A., Han, E., Chung, H. and Li, J.-H. (2017) New Psychoactive Substances of Natural Origin: A Brief Review. Journal of Food and Drug Analysis, 25, 461-471. https://doi.org/10.1016/j.jfda.2017.04.001

[18] Dhabbah, A.M. (2020) Determination of Chiral Cathinone in Fresh Samples of Catha edulis. Forensic Science International, 307, Article ID: 110105. https://doi.org/10.1016/j.forsciint.2019.110105

[19] Ongeri, L., Kirui, F., Muniu, E., et al. (2019) Khat Use and Psychotic Symptoms in a Rural Khat Growing Population in Kenya: A Household Survey. BMC Psychiatry, 19, 137. https://doi.org/10.1186/s12888-019-2118-3 
[20] Mihretu, A., Teferra, S. and Fekadu, A. (2017) What Constitutes Problematic Khat Use? An Exploratory Mixed Methods Study in Ethiopia. Substance Abuse Treatment, Prevention, and Policy, 12, Article No. 17. https://doi.org/10.1186/s13011-017-0100-y

[21] Gudata, Z.G., Cochrane, L. and Imana, G. (2019) An Assessment of Khat Consumption Habit and Its Linkage to Household Economies and Work Culture: The Case of Harar City. PLOS ONE, 14, e0224606. https://doi.org/10.1371/journal.pone.0224606

[22] MedicineNet. (2020) Khat. https://www.medicinenet.com/khat/article.htm\#

[23] Ademe, B.W., Brimer, L., Dalsgaard, A. and Belachew, T. (2020) Chemical and Microbiological Hazards of Khat (Catha edulis) from Field to Chewing in Ethiopia. GSC Biological and Pharmaceutical Sciences, 11, 24-35. https://doi.org/10.30574/gscbps.2020.11.1.0038

[24] European Monitoring Centre for Drugs and Drug Addiction (2020) Synthetic Cathinones Drug Profile.

https://www.emcdda.europa.eu/publications/drug-profiles/synthetic-cathinones_en

[25] Abebe, W. (2018) Khat and Synthetic Cathinones: Emerging Drugs of Abuse with Dental Implications. Oral Surgery, Oral Medicine, Oral Pathology and Oral Radiology, 125, 140-146. https://doi.org/10.1016/j.oooo.2017.11.015

[26] Wolff, V., Armspach, J. and Lauer, V. (2018) Street Drugs II: Amphetamine Derivatives and Hallucinogens. In: Valani, R., Ed., Essentials of Pediatric Emergency Medicine, Brush Education, Edmonton, 376.

[27] Prosser, J.M. and Nelson, L.S. (2012) The Toxicology of Bath Salts: A Review of Synthetic Cathinones. Journal of Medical Toxicology, 8, 33-42.

https://doi.org/10.1007/s13181-011-0193-Z

[28] Dunne, F.J., Jaffar, K. and Hashmi, S. (2015) Legal Highs-Not so New and Still Growing in Popularity. British Journal of Medical Practitioners, 8, 25-33.

[29] Drugs.com. (2019) Khat. https://www.drugs.com/npp/khat.html

[30] Atlabachew, M., Chandravanshi, B.S. and Redi, M. (2014) Selected Secondary Metabolites and Antioxidant Activity of Khat (Catha edulis Forsk) Chewing Leaves Extract. International Journal of Food Properties, 17, 45-64. https://doi.org/10.1080/10942912.2011.614367

[31] Jerah, A., Bidwai, A.K. and Alam, M.S. (2017) A Review of the History, Cultivation, Chemistry, Pharmacology and Adverse Health Effects of Khat. International Journal of Applied and Natural Sciences, 6, 45-62.

[32] Atlabachew, M., Chandravanshi, B.S. and Redi-Abshiro, M. (2017) Preparative HPLC for Large Scale Isolation, and Salting-Out Assisted Liquid-Liquid Extraction Based Method for HPLC-DAD Determination of Khat (Catha edulis Forsk) Alkaloids. Chemistry Central Journal, 11, Article No. 107. https://doi.org/10.1186/s13065-017-0337-6

[33] Gashawa, A. and Getachew, T. (2014) The Chemistry of Khat and Adverse Effect of Khat Chewing. American Scientific Research Journal for Engineering, Technology, and Sciences, 9, 35-46.

[34] Leon, M.E., Assefa, M., Kassa, E., Bane, A., Gemechu, T., Tilahun, Y., et al. (2017) Qat Use and Esophageal Cancer in Ethiopia: A Pilot Case-Control Study. PLoS ONE, 12, e0178911. https://doi.org/10.1371/journal.pone.0178911

[35] Hassan, A.A., Hobani, Y.H., Mosbah, N., Abdalla, S.E., Zaino, M., Mohan, S., et al. (2020) Chronic Khat (Catha edulis) Chewing and Genotoxicity: The Role of Anti- 
oxidant Defense System and Oxidative Damage of DNA. Pharmacognosy Magazine, 16, 168-173. https://doi.org/10.4103/pm.pm_455_19

[36] Nigussie, T., Gobena, T. and Mossie, A. (2013) Association between Khat Chewing and Gastrointestinal Disorders: A Cross Sectional Study. Ethiopian Journal of Health Sciences, 23, 123-130. https://pubmed.ncbi.nlm.nih.gov/23950628

[37] Lu, Y., Li, Y., Xiang, M., Zhou, J. and Chen, J. (2017) Khat Promotes Human Breast Cancer MDA-MB-231 Cell Apoptosis via Mitochondria and MAPK-Associated Pathways. Oncology Letters, 14, 3947-3952. https://doi.org/10.3892/ol.2017.6708

[38] Girma, T., Mossie, A. and Getu, Y. (2015) Association between Body Composition and Khat Chewing in Ethiopian Adults. BMC Research Notes, 8, Article No. 680. https://doi.org/10.1186/s13104-015-1601-2

[39] Muema, E.K. (2015) Biochemical, Hormonal and Toxicological Effects of Catha edulis (Khat) on Pregnancy and Fetal Development in Olive baboons (Papio anubis). University of Nairobi, Nairobi.

[40] Lukandu, O.M., Koech, L.S. and Kiarie, P.N. (2015) Oral Lesions Induced by Chronic Khat Use Consist Essentially of Thickened Hyperkeratinized Epithelium. International Journal of Dentistry, 2015, Article ID: 104812. https://doi.org/10.1155/2015/104812

[41] Alshagga, M.A., Alshawsh, M.A., Seyedan, A., Alsalahi, A., Pan, Y., Mohankumar, S.K., et al. (2016) Khat (Catha edulis) and Obesity: A Scoping Review of Animal and Human Studies. Annals of Nutrition and Metabolism, 69, 200-211. https://doi.org/10.1159/000452895

[42] Zeng, Q.-L., Yu, Z.-J., Gou, J.-J., Li, G.-M., Ma, S.-H., Zhang, G.-F., et al. (2020) Effect of Convalescent Plasma Therapy on Viral Shedding and Survival in Patients with Coronavirus Disease 2019. The Journal of Infectious Diseases, 222, 38-43. https://doi.org/10.1093/infdis/jiaa228

[43] World Health Organization (2020) Coronavirus Disease 2019 (COVID-19). Situation Report, No. 88.

https://www.who.int/docs/default-source/coronaviruse/situation-reports/20200417sitrep-88-covid-19

[44] Wilder-Smith, A. and Freedman, D.O. (2020) Isolation, Quarantine, Social Distancing and Community Containment: Pivotal Role for Old-Style Public Health Measures in the Novel Coronavirus (2019-nCoV) Outbreak. Journal of Travel Medicine, 27, taaa20. https://doi.org/10.1093/jtm/taaa020

[45] Centres for Disease Control and Prevention (2020) Social Distancing. https://www.cdc.gov/coronavirus/2019-ncov/prevent-getting-sick/social-distancing. $\underline{\mathrm{html}}$

[46] Wabe, N.T. (2011) Chemistry, Pharmacology, and Toxicology of Khat (Catha edulis Forsk): A Review. Addiction and Health, 3, 137-149.

https://pubmed.ncbi.nlm.nih.gov/24494129

[47] Otter, J.A., Donskey, C., Yezli, S., Douthwaite, S., Goldenberg, S.D. and Weber, D.J. (2016) Transmission of SARS and MERS Coronaviruses and Influenza Virus in Healthcare Settings: The Possible Role of Dry Surface Contamination. Journal of Hospital Infection, 92, 235-250. https://doi.org/10.1016/j.jhin.2015.08.027

[48] Chan, K.-H., Peiris, J.M., Lam, S., Poon, L., Yuen, K. and Seto, W.H. (2011) The Effects of Temperature and Relative Humidity on the Viability of the SARS Coronavirus. Advances in Virology, 2011, Article ID: 734690. https://doi.org/10.1155/2011/734690

[49] Harrison, X.A., Donaldson, L., Correa-Cano, M.E., Evans, J., Fisher, D.N., Good- 
win, C.E., et al. (2018) A Brief Introduction to Mixed Effects Modelling and Multi-Model Inference in Ecology. PeerJ, 6, e3113v2. https://doi.org/10.7287/peerj.preprints.3113v2

[50] Bartocci, E. and Lió, P. (2016) Computational Modeling, Formal Analysis, and Tools for Systems Biology. PLoS Computational Biology, 12, e1004591. https://doi.org/10.1371/journal.pcbi.1004591

[51] Nyshadham, C., Oses, C., Hansen, J.E., Takeuchi, I., Curtarolo, S. and Hart, G.L. (2017) A Computational High-Throughput Search for New Ternary Superalloys. Acta Materialia, 122, 438-447. https://doi.org/10.1016/j.actamat.2016.09.017

[52] Sokolowski, J.A. and Banks, C.M. (2011) Principles of Modeling and Simulation: A Multidisciplinary Approach. John Wiley \& Sons, Hoboken.

[53] Kirkok, S.K., Kibet, J.K., Okanga, F., Kinyanjui, T. and Nyamori, V. (2019) Mechanistic Formation of Hazardous Molecular Heterocyclic Amines from High Temperature Pyrolysis of Model Biomass Materials: Cellulose and Tyrosine. BMC Chemistry, 13, Article No. 126. https://doi.org/10.1186/s13065-019-0644-1

[54] Chong, Z.X., Ho, W.Y., Yan, P. and Alshagga, M.A. (2020) Evaluation of Khat (Catha edulis) Use as a Risk Factor of Cancer: A Systematic Review. Asian Pacific Organization for Cancer Prevention, 21, 881-895. https://dx.doi.org/10.31557/APJCP.2020.21.4.881

[55] Mosonik, B.C., Ngari, S.M. and Kibet, J.K. (2019) Molecular Modelling of Selected Combustion By-Products from the Thermal Degradation of Croton Megalocarpus Biodiesel. Open Access Library Journal, 6, 1-12.

[56] Harati, B., Shahtaheri, S.J., Karimi, A., Azam, K., Ahmadi, A., Rad, M.A., et al. (2016) Cancer Risk Analysis of Benzene and Ethyl Benzene in Painters. Basic \& Clinical Cancer Research, 8, 22-28.

[57] Centers for Disease Control and Prevention (2018) Facts about Benzene. https://emergency.cdc.gov/agent/benzene/basics/facts.asp\#: :text=(Long\%2Dterm\% 20exposure $\% 20$ means $\% 20$ exposure,increasing $\% 20$ the $\% 20$ chance $\% 20$ for $\% 20$ infectio $\underline{\mathrm{n}}$

[58] Gao, P., Yao, D.C., Qian, Y.J., Zhong, S., Zhang, L.S., Xue, G. and Jia, H.Z. (2018) Factors Controlling the Formation of Persistent Free Radicals in Hydrochar during Hydrothermal Conversion of Rice Straw. Environmental Chemistry Letters, 16, 1463-1468. https://doi.org/10.1007/s10311-018-0757-0

[59] Pan, B., Li, H., Lang, D. and Xing, B.S. (2019) Environmentally Persistent Free Radicals: Occurrence, Formation Mechanisms and Implications. Environmental Pollution, 248, 320-331. https://doi.org/10.1016/j.envpol.2019.02.032

[60] D’Arienzo, M., Gamba, L., Morazzoni, F., Cosentino, U., Greco, C., Lasagni, M., et al. (2017) Experimental and Theoretical Investigation on the Catalytic Generation of Environmentally Persistent Free Radicals from Benzene. The Journal of Physical Chemistry C, 121, 9381-9393. https://doi.org/10.1021/acs.jpcc.7b01449

[61] Zhu, Y.H., Wei, J., Liu, Y.T., Liu, X.H., Li, J. and Zhang, J. (2019) Assessing the Effect on the Generation of Environmentally Persistent Free Radicals in Hydrothermal Carbonization of Sewage Sludge. Scientific Reports, 9, Article No. 17092. https://doi.org/10.1038/s41598-019-53781-3

[62] Larijani, H.T., Jahanshahi, M., Ganji, M.D. and Kiani, M. (2017) Computational Studies on the Interactions of Glycine Amino Acid with Graphene, h-BN and h-SiC Monolayers. Physical Chemistry Chemical Physics, 19, 1896-1908. https://doi.org/10.1039/C6CP06672K

[63] Kibet, J. (2016) Computational Modeling of 2-Monochlorophenol and 2- Monoch- 
lorothiophenol. Kabarak Journal of Research \& Innovation, 4, 49-61.

[64] Marahatta, A.B. (2020) Computational Study on Electronic Structure, Atomic Charges Distribution and Frontier Molecular Orbitals of Butadiene: General Features for Diels-Alder Reaction. The International Journal of Progressive Sciences and Technologies, 19, 48-64.

[65] Wang, C.-M., Liu, Z.-H., Chen, Y.-K., Han, J.-M., Chen, Y.-L., Miao, M.-M., et al. (2013) An $A b$ initio Analysis of the Diels-Alder Reaction between Two Isoprenes. Computational and Theoretical Chemistry, 1017, 174-181.

https://doi.org/10.1016/j.comptc.2013.05.023

[66] Silva, C.F., Borges, K.B. and Nascimento, C.S. (2019) Computational Study on Acetamiprid-Molecular Imprinted Polymer. Journal of Molecular Modeling, 25, Article No. 104. https://doi.org/10.1007/s00894-019-3990-y 